J. Dairy Sci. 97:2527-2527

http://dx.doi.org/10.3168/jds.2013-7104

(C) American Dairy Science Association ${ }^{\circledR}, 2014$.

\title{
Letter to the editor: The claimed synergistic action of prednisolone and cefapirin in mastitis therapy: A comment on Sipka et al. (2013)
}

\author{
Satu Pyörälä ${ }^{1}$ \\ Department of Production Animal Medicine, Faculty of Veterinary Medicine, University of Helsinki, FI-04920 Saarentaus, Finland
}

A recent paper published in the Journal of Dairy Science (Sipka et al., 2013) is worthy of comment. The title states that prednisolone and cefapirin act synergistically in resolving experimental Escherichia coli mastitis. By definition, synergistic action means that the combined effects of drugs are significantly greater than the sum of the independent effects. Did this study actually demonstrate that kind of effect? According to the study design, several quarters were challenged in the same cow. Quarters were handled as if they were separate experimental units, but quarters may have interactions through systemic effects and drugs may distribute between them. Could this interfere with the results? The only significant effects found for the combination of prednisolone and cefapirin were the lower concentrations of IL- 4 at $24 \mathrm{~h}$ and slower leukocyte recruitment in tissue at 24 and $48 \mathrm{~h}$. This evidence seems scarce to support the statement in the abstract that adding prednisolone resulted in quicker restoration of milk quality. No difference between treatments was found in milk SCC (Figure 4 in Sipka et al., 2013), but data from the California Mastitis Test (CMT) were used to support the results for prednisolone; the CMT result is just an estimate of SCC, which is a more accurate, numeric parameter. The section on statistical analysis did not mention how the CMT data were handled. Recruitment of PMNL to tissue is an interesting issue. Recruitment of PMNL in the prednisolone group $(\mathrm{n}=3)$ was similar to that of the control group (not infected) at $24 \mathrm{~h}$, but no difference was seen at $48 \mathrm{~h}$. Is slowing down the recruitment of PMNL a beneficial effect in terms of clearance of infection? As in many experiments on nonsteroidal antiinflammatory drugs, treatment was administered before the onset of clinical signs, in this case at $4 \mathrm{~h}$ postchallenge. This should be taken into account when evaluating the clinical relevance. Currently, the scientific literature does not support the use of corticosteroids in mastitis therapy (as reviewed by Suojala et al., 2013). Some claimed beneficial effects at certain time points reported for corticosteroids administered at challenge or shortly after do not provide enough evidence for clinical situations. Further clinical studies are necessary before considering the use of combination therapy in Escherichia coli mastitis.

\section{REFERENCES}

Sipka, A., A. Gurjar, S. Klaessig, G. E. Duhamel, A. Skidmore, J. Swinkels, P. Cox, and Y. Schukken. 2013. Prednisolone and cefapirin act synergistically in resolving experimental Escherichia coli mastitis. J. Dairy Sci. 96:4406-4418. http://dx.doi.org/10.3168/ jds.2012-6455.

Suojala, L., L. Kaartinen, and S. Pyörälä. 2013. Treatment for bovine Escherichia coli mastitis - An evidence-based approach. J. Vet. Pharmacol. Therap. 36:521-531. http://dx.doi.org/10.1111/ jvp.12057.

Received June 6, 2013.

Accepted January 21, 2014.

${ }^{1}$ Corresponding author: satu.pyorala@helsinki.fi 